Egyptian Journal for Aquaculture

ISSN: 2090-7877

www.braesd.org

Goda etal., 2019; 9(1):25-48

\title{
Use of high protein distiller's dried grains (HPDDG) with enzyme phytase as a cost effective ingredient in the diet of fingerlings European sea bass, Dicentrarchus labrax
}

\author{
Ashraf M.A.-S. Goda ${ }^{1}$, Eglal Omar ${ }^{2}$, Tarek M. Srour ${ }^{2}$, Abdallah T. \\ Mansour ${ }^{2}$, Mohamed Z. Baromh', Hani M. Nazmi ${ }^{1}$, Sherine A.Ragab ${ }^{1}$ \\ ${ }^{1}$ National Institute of Oceanography and Fisheries (NIOF), Alexandria, Egypt. \\ ${ }^{2}$ Fish and Animal Production Department, Faculty of Agriculture (Saba Basha), \\ Alexandria University, Egypt.
}

Received: Nov. 25, 2018; Accepted: Sept. 19, 2018 Vol.9 (1):25-48; 2019

\section{ABSTRACT}

The present study was conducted to evaluate the effect of various dietary levels of high protein distiller's dried grains (HPDDG) supplemented with enzyme phytase on growth performance, feed utilization and haematological indices of European sea bass Dicentrarchus labrax fingerlings. A total of $150 \mathrm{D}$. labrax fingerlings with an average body weight of $7.5 \pm 0.5 \mathrm{~g}$ were divided in the five experimental treatments (in triplicates each). The experiment was conducted for 56 days. Fish were fed to apparent the satiation six days a week. Five isonitrogenous $45 \% \quad \mathrm{CP}$ experimental diets were formulated. The control (C) diet had no high protein distiller's dried grains (HPDDG) and phytase enzyme added. Diet $2\left(\mathrm{C}^{+}\right)$was formulated as control diet and supplemented with phytase at a level of $0.5 \mathrm{~g} / \mathrm{kg}$. Diets 3-5 each contained HPDDG at levels of 20,30 , and $40 \%$, respectively with soybean meal and supplemented each with phytase at a level of $0.5 \mathrm{~g} / \mathrm{kg}$. Over the 56 days feeding period, all fish fed HPDDG-supplemented with phytase diets resulted in higher growth than the control diet, suggesting that the using of HPDDG-supplemented with phytase enhanced the growth performance of sea bass fingerlings. The same trend was recorded for the best FCR and PER. The hematology and serum biochemistry (hemoglobin $(\mathrm{Hb})$, red blood cells (RBCs) count, white blood cells (WBCs) and hematocrit (Hct $\%$ ) and immune parameters (total protein, albumin, globulin, cholestorl, lysozyme activity and total antioxidant capacity) 
of D. labrax fingerlings significantly $(\mathrm{P} \geq 0.05)$ increased with increasing dietary HPDDG with phytase. Result indicates that HPDDG with phytase is a good alternative protein source for compromising growth performance and physiological parameters of European sea bass, Dicentrarchus labrax Fingerlings.

Keywords: Dicentrarchuslabrax, high protein distillers dried grains, phytase, physiological parameters, growth.

\section{Introduction}

Aquaculture is one the fastest growing agriculture industries in the world. Globally, in 2016, aquaculture was responsible for the production of 171 million tons of fish products, most of which was for human consumption (FAO, 2018). With the world's population projected to reach 9.7 billion people by 2050 and global capture fisheries unstable and steadily declining, the spotlight turns to aquaculture production to contribute significantly to global food security and adequate global nutrition and human health (NASS, 2016).

More than $70 \%$ of the total global aquaculture production is dependent upon the supply of external feed inputs. For the aquaculture sector to maintain its current growth rate, the supply of nutrient and feed inputs will have to grow at a similar rate, while aquatic ingredients production remains static and other sectors compete for same feed resources.

Distillers' dried grains with soluble (DDGS), which are the by-product of cereal distillation for ethanol production. Except for the starch fraction, which is consumed during fermentation, DGGS's nutrient content is almost 3 times more concentrated than the original grain, thus containing higher protein, lipid and fiber levels (Liu, 2011). The protein content in DDGS ranges from 25 to $45 \%$, depending on the grain source, and has reduced anti-nutritional factors comparatively to most plant protein sources. Studies on DDGS incorporation in aqua-feeds studies were mainly done in omnivorous fish species, such as channel catfish, Ictalurus punctatus; (Li et al., 2011a), Nile tilapia, Oreochromis niloticus and hybrid tilapia, Oreochromis niloticus $\times$ Oreochromis aureus (Welker et al., 2014a). So far, studies performed on the potential use of DDGS in carnivorous species are limited to a few studies with rainbow trout, Oncorhynchus mykiss (Overland et al., 2013; Welker et al., 2014b), olive flounder, Paralichthy solivaceus (Rahman et al., 2015; 
Bae et al., 2015), and meager, Argyrosomus regius (Magalhães et al., 2016).

Currently, the use of various enzymes in aquatic feed has been on the rise to improve the overall quality of diets containing these economical protein sources. Use exogenous enzymes to feeds could improve the growth performance by means of enhancing nutrient digestibility (Farhangi and Carter, 2007), increasing activities of digestive enzymes (Lin et al., 2007), and improving the histological structure (Mathlouthi et al., 2002) and the health of intestine (reviewed by Castillo and Gatlin, 2015). They include phytase (Liu et al. 2013), protease (Dalsgaard $\boldsymbol{e t}$ al. 2012), and xylanase (Nie et al. 2009). In addition, exogenous enzymes have been used extensively throughout the world as additives in animal diets. The use of these exogenous enzymes has been shown to affect the digestibility of nutrients, including protein, carbohydrates and minerals (Forster et al. 1999). However, supplementation enzymes help to eliminate the effects of anti-nutritional factors and improve the utilization of dietary energy and amino acids, resulting in improved fish performance (Soltan 2009). The effects of enzyme supplementation on the growth and survival of several cultured fish species have been demonstrated by several researchers; rainbow trout, Oncorhynchus mykiss (Dalsgaard et al., 2014), tilapia,Oreochromis niloticus $\times O$. aureus (Li et al., 2015), common carp, Cyprinus carpio (Leng et al., 2008), Atlantic salmon, Salmo salar L. (Carter et al., 1994), and white shrimp, Litopenaeus vannamei (Li et al., 2015) but, there are few published reports on the effect of adding enzymes to diets for sea bass on feed utilization, growth performance and mineral utilization. Phytic acid, a known anti-nutrient, in the diets of non-ruminants can significantly affect growth and overall health of animals, through the formation of complexes with proteins and divalent cations (Dersjant-Li et al. 2015). Phytic acid is prevalent in plant matter, and especially abundant in ingredients such as cottonseed meal, wheat middlings, and soybean meal. The commercial poultry and swine industries have reported the use of phytases to aid in the destruction of phytic acid and increase bioavailability of minerals, protein, and the absorption of phosphorus (Selle and Ravindran, 2007).

The present study was undertaken to determine the effect of various dietary levels of high protein distiller's dried grains (HPDDG) supplemented with enzyme phytase on growth performance, feed 
utilization and haematological indices of European sea bass Dicentrarchus labrax fingerlings.

\section{Material and Methods}

\section{Fish and experimental facilities}

Total 150 fingerlings of European sea bass, Dicentrarchus labrax with an average initial body weight of $7.5 \pm 0.5 \mathrm{~g} /$ fish was obtained from a private commercial fish farm (El- Shref farm, Wady Marriott, Alexandria). During fish acclimation for one week in indoors circular fiberglass tanks ( 1 cubic meter), fish was fed experiment diet contained $45 \%$ crude protein. Then, fish were randomly distributed into 15 glass aquaria measuring $(70 \times 40 \times 30 \mathrm{~cm}$ each) (five treatments, each in triplicate) at a stocking density of 10 fish per aquaria. Daily water exchange rate was $50 \%$ underground salinity water (37 ppt). Water temperature, dissolved oxygen, $\mathrm{pH}$, and ammonia were monitored during the trial, to maintain water quality at optimum range for D. labrax. Water temperature was maintain at $18 \pm 1.0^{\circ} \mathrm{C}$, dissolved oxygen (DO) at 5.7 $\mathrm{mg} / \mathrm{L}$ and $\mathrm{pH}$ at $7.0 \pm 0.50$. Fish was held under natural light $(12: 12 \mathrm{~h}$ light:dark schedule).

\section{Experimental design and diets}

Five isonitrogenous (45\% CP) and isolipidic (11\% EE) experimental diets were formulated (Table 1). The control (C) diet had no high protein distiller's dried grains (HPDDG) and phytase enzyme added. Diet $2\left(\mathrm{C}^{+}\right)$ was formulated as control diet and supplemented with phytase at a level of $0.5 \mathrm{~g} / \mathrm{kg}$. Diets 3-5 each contained HPDDG at levels of 20,30, and 40 $\%$, respectively and supplemented each with phytase at a level of 0.5 $\mathrm{g} / \mathrm{kg}$. The daily ration was divided into two equal amounts and offered two times a day (09.00 and $13.00 \mathrm{~h}$ ). The fish were fed one of the five experimental diets for 56 days, six days a week.

Experimental diets were prepared by mixing the dry ingredients of each diet were thoroughly mixed and $200 \mathrm{ml}$ of water was added per $\mathrm{kg}$ diet thereafter, the mixture (ingredients and water) was blender to make a paste of each diet. pelleting of each diet was carried out by passing the blended mixture through laboratory pellet matching was a $1 \mathrm{~mm}$ diameter matrix, the resulting wet pellet were dried at room temperature for two days. The diets were stored in plastic bags in refrigerator $\left(-2^{\circ} \mathrm{C}\right)$ until use. 
Table (1): Shows the feed ingredients (\%) and chemical composition (\%) of the diet.

\begin{tabular}{|c|c|c|c|c|c|}
\hline \multirow{2}{*}{ Ingredients } & \multicolumn{5}{|c|}{ Experimental Diets } \\
\hline & $\begin{array}{l}\text { Control } \\
\text { (C) }\end{array}$ & $\mathrm{C}^{+}$ & $\mathrm{D}_{20 \%}{ }^{+}$ & $\mathrm{D}_{30 \%}{ }^{+}$ & $\mathrm{D}_{40 \%}{ }^{+}$ \\
\hline Fish meal (68\% CP) & 300.00 & 300.00 & 300.00 & 300.00 & 300.00 \\
\hline Soy bean meal (47\% CP) & 375.00 & 375.00 & 262.50 & 225.00 & 187.50 \\
\hline Corn gluten $(60 \% \mathrm{CP})$ & 90.00 & 89.5 & 89.50 & 89.50 & 89.50 \\
\hline Rice bran $(12 \% \mathrm{CP})$ & 65.00 & 65.00 & 50.00 & 50.00 & 50.00 \\
\hline Wheat medling $(13 \% \mathrm{CP})$ & 70.00 & 70.00 & 83.80 & 84.80 & 85.80 \\
\hline HDDGS (47\% CP) & 0.00 & 0.00 & 112.50 & 150.00 & 187.50 \\
\hline Soy bean oil & 40.00 & 40.00 & 41.00 & 40.00 & 40.00 \\
\hline Fish oil & 48.8 & 48.8 & 49.00 & 49.00 & 48.00 \\
\hline Di-calcium phosphate & 8.00 & 8.00 & 8.00 & 8.00 & 8.00 \\
\hline Premix $^{1}$ & 2.00 & 2.00 & 2.00 & 2.00 & 2.00 \\
\hline Vit. C & 0.20 & 0.20 & 0.20 & 0.20 & 0.20 \\
\hline Antytocsec & 1.00 & 1.00 & 1.00 & 1.00 & 1.00 \\
\hline Phytase & 0.00 & 0.50 & 0.50 & 0.50 & 0.50 \\
\hline \multicolumn{6}{|c|}{ Chemical composition ( $\%$, dry matter basis) } \\
\hline Dry matter (DM) & 93.80 & 93.80 & 93.77 & 93.80 & 93.60 \\
\hline Crude protein $(\mathrm{CP})$ & 44.10 & 44.10 & 44.40 & 44.97 & 45.20 \\
\hline Ether extract (EE) & 12.56 & 12.56 & 11.00 & 10.48 & 9.96 \\
\hline Nitrogen free extract $(\mathrm{NFE})^{2}$ & 29.09 & 29.09 & 30.50 & 31.15 & 30.74 \\
\hline Crude fiber (CF) & 3.25 & 3.25 & 4.30 & 3.40 & 3.10 \\
\hline Ash & 11.00 & 11.00 & 9.80 & 10.00 & 11.00 \\
\hline Gross energy $(\mathrm{GE} ; \mathrm{Mj} / \mathrm{kg} \mathrm{DM})^{3}$ & 20.93 & 20.93 & 20.81 & 20.70 & 20.42 \\
\hline \multicolumn{6}{|c|}{$\begin{array}{l}\text { Vitamin and mineral mixture (supplements per } \mathrm{kg} \text { of the mixed feed): vitamin } \mathrm{A} \text {, } \\
4,500 \mathrm{IU} \text {; vitamin } \mathrm{D} 3,4,500 \mathrm{IU} \text {; vitamin } \mathrm{E}, 400 \mathrm{mg} \text {; vitamin } \mathrm{B} 1,30 \mathrm{mg} \text {; vitamin } \mathrm{B} 2,40 \\
\mathrm{mg} \text {; vitamin B6, } 40 \mathrm{mg} \text {; vitamin B12, } 0.08 \mathrm{mg} \text {; vitamin } \mathrm{K} 3,15 \mathrm{mg} \text {; ascorbic acid, } 750 \\
\text { mg; nicotinic acid, } 300 \mathrm{mg} \text {; Ca-pantothenate, } 100 \mathrm{mg} \text {; folic acid, } 10 \mathrm{mg} \text {; biotin, } 3 \mathrm{mg} \text {; } \\
\text { inositol, } 500 \mathrm{mg} \text {; p-amino benzoic acid, } 200 \mathrm{mg} \text {; Ca, } 2.1 \mathrm{~g} \text {; Fe, } 250 \mathrm{mg} \text {; Mn, } 40 \mathrm{mg} ; \mathrm{Zn} \text {, } \\
60 \mathrm{mg} \text {; I, } 4 \mathrm{mg} \text {; Cu, } 12 \mathrm{mg} \text {; Se, } 0.3 \mathrm{mg} \text {; Co, } 2 \mathrm{mg}{ }^{2} \mathrm{NFE} \text { : calculated using the following } \\
\text { equation: NFE = } 100 \text { (crude protein + ether extract + crude fiber + ash). }{ }^{3} \mathrm{Gross} \text { energy } \\
\text { (GE) contents of diets were calculated according to gross caloric values of Brett (1973) } \\
\text { using the values of } 23.6,39.5 \text {, and } 17.2 \mathrm{kJg}^{-1} \text { for crude protein, crude fat, and total } \\
\text { carbohydrate, respectively. }\end{array}$} \\
\hline
\end{tabular}


Commercial phytase enzyme product was used for supplementation of the experimental diets at levels of $0.5 \mathrm{~g} / \mathrm{kg}$ diet. One gram phytase contains the enzymatic activity of 5000 Phytase Units (FTU), phytase was dissolved into $100 \mathrm{~mL}$ water at $37{ }^{\circ} \mathrm{C}$ (Yoo et al., 2005). The solution was added to the experimental diets and incubated for 24 hours at room temperature according to the method of Danwitz et al., (2016). Pellets were stored in the refrigerator at $-4{ }^{\circ} \mathrm{C}$ (Ambasankar et al., 2009).

\section{Growth Indices}

The mean final body weight (FBW) in experimental treatment was determined by dividing the total fish weight in each aquarium by the number of fish. Body weight gain (BWG), feed conversion ratio (FCR), protein efficiency ratio (PER) and specific growth rate (SGR) were calculated using the following equations, according to Cho (1990) and Castell and Tiews (1980):

BWG = final body weight $(\mathrm{g})$ - initial body weight $(\mathrm{g})$.

$\mathrm{FCR}=$ feed intake $(\mathrm{g}) /$ weight gain $(\mathrm{g})$.

SGR $(\% /$ day $)=100 \times[(\ln$ final body weight $(\mathrm{g})-\ln$ initial body weight $(\mathrm{g})) /$ duration of feeding (day)].

PER = weight gain $(\mathrm{g}) /$ protein intake $(\mathrm{g})$

\section{Blood Sampling}

Blood samples were collected at the end of the experiment. Each of the experimental treatment was sampled once, with five fish/ net enclosure for hematological indices analysis and five fish/ net enclosure bled for plasma content analysis. The fish were anesthetized with t-amyl alcohol and the blood samples were taken by puncturing the caudal vessels. The collected blood was divided into two tubes, one containing heparin as anticoagulant agent for haematological assessment and the other was anticoagulant free for biochemical estimation. The haematological parameters are expressed in international units (SI).

The total red and white blood cell counts (RBC; $10^{6} \mathrm{~mm}^{-3}$ and WBC; $10^{3} \mathrm{~mm}-3$, respectively) were obtained by using a standard Neubauerhemocytometer chamber using Shaw's solution as diluting fluid (Stoskopf, 1993).Hemoglobin ( $\mathrm{Hb} ; \mathrm{g} / \mathrm{dL}^{-1}$ ) was determined colorimetrically using commercial kits (Diamond, Egypt) according to cyanmethemoglobin procedure (Drabkin, 1945 and Stoskopf, 1993).

The total protein $\left(\mathrm{g} \mathrm{dL}^{-1}\right)$ was determined in plasma samples of fish from the different experimental groups by the Biuret method according to 
(Doumas et al. 1981) .Albumin $\left(\mathrm{g} \mathrm{dL}^{-1}\right)$ was determined by the bromocresol green method (Reinhold ,1953) and globulin $\left(\mathrm{g} \mathrm{dL}^{-1}\right)$ was calculated as the difference between total protein and albumin. Cholesterol using a commercial kit (Pasteur, Lab, France, Egypt) (Yousefi et al. 2011).

Lysozyme activity ( $\mathrm{U} \mathrm{mg} \mathrm{mg}^{-1}$ protein) in serum was determined according to the method of Kim and Austin, (2006) and Ellis, (1990) based on the lysis of the lysozyme sensitive gram-positive bacterium Micrococcus lysodiekticus (Sigma, St. Louis, MO). Lysozyme acts upon susceptible bacteria by combining with and breaking down a mucopolysaccharide. This mucopolysaccharidehas been shown to be situated in the bacterial cell wall. M. lysodeikticus, one of the gram positive bacteria, is normally highly sensitive to lysozyme. 3 dilutions of hen egg white lysozyme (Sigma) ranging from 0 to $25 \mu \mathrm{g} \mathrm{mL}^{-1}$ (in $0.1 \mathrm{M}$ phosphate-citrate buffer, pH 6) (Sigma, USA) were used as the standard. Prepared standard solutions were placed along with the undiluted serum sample $(25 \mu \mathrm{L})$ in the wells of a 96 -well plate in triplicate, $175 \mu \mathrm{L}$ of $\mathrm{M}$. lysodiekticussuspension ( $750 \mu \mathrm{g} \mathrm{mL}-1)$ was prepared in the same buffer

Total antioxidant capacity (TAC) level was estimated spectrophotometrically at $532 \mathrm{~nm}$ following the method with Tween 80 oxidation (Galaktionova et al. 1998 and Prieto et al. 1999). Briefly, 0.2 $\mathrm{ml}$ of tissue homogenate was added to $2 \mathrm{ml}$ of $1 \%$ Tween 80 . Instead of the sample, the blank assay included $0.1 \mathrm{ml}$ of distilled water. The mixture was incubated for 48 hours at $37^{\circ} \mathrm{C}$. After cooling, $1 \mathrm{ml}$ of $40 \%$ TCA was added. The mixture was centrifuged at 3,000 $\mathrm{g}$ for $10 \mathrm{~min}$. After centrifugation, $2 \mathrm{ml}$ of supernatant and $2 \mathrm{ml}$ of $0.25 \%$ TBA reagent were mixed in. The mixture was heated in a boiling water bath at $100{ }^{\circ} \mathrm{C}$ for 15 minutes. The absorbance of the solution obtained was measured at $532 \mathrm{~nm}$ and was compared with the blank. The TAC level was expressed in $\%$.

\section{Statistical analysis:}

One-way ANOVA and Duncan's, (1955) multiple range tests were calculated effects with a probability of $\mathrm{p}<0.05$ were considered significant. The data of the experiments were statistically analyzed using GLM (general linear model) procedure according to Statistical Analysis System (SAS 2004). However, data are presented untransformed to 
facilitate comparisons. The relationship between hematological indices was tested using simple correlation analysis.

\section{Results and Discussion}

The use plant feedstuff such as (wheat gluten, soybean meal, soy protein concentrate) imposes some concerns due to the "food-feed competition", rising prices, and carbon footprint involved in their production and importation (Bonaldo et al., 2015). Thus, there is an increasing need to look for alternatives, particularly underutilized commodities, such as by-products obtained from food, fermentation and pharmaceutical industries, which is highly dependent of imported plant feedstuffs, as soybean meals, for aqua-feeds formulation (Matos et al. 2016). Within these alternative plant feedstuffs, distillers' dried grains with solubles (DDGS) can consider, which are the by-product of cereal distillation for ethanol production. Except for the starch fraction, which is consumed during fermentation, DGGS's nutrient content is almost 3 times more concentrated than the original grain, thus containing higher protein, lipid and fiber levels (Liu, 2011). Recently, the majority of the dry-grind ethanol plants produced a DDGS by-product containing 26$34 \%$ protein, depending on the grain source, and has reduced antinutritional factors comparatively to most plant protein sources. (Rosentrater and Muthukumarappan 2006). However, many ethanol plants are implementing a modified dry milling process called fractionation to increase ethanol yields. In this new process, whole corn is milled, then sorted into separate fractions: corn germ, bran, and the endosperm (which is used for ethanol fermentation). The two main coproducts of the modified process are corn germ and high-protein distiller's dried grains (HP-DDG). This HP-DDG product has a protein level of 43-49\% and lower levels of fat and phosphorus than that in traditional DDGS because it does not contain the solubles component that would normally be added back to the distiller's dried grains (Tidwell et al. 2017). The higher protein content of HP-DDG could make them even more attractive for inclusion in fish diets because protein is generally the most expensive nutrient component in aqua-feeds. 
Table (2): Growth performance of European sea bass, Dicentrarchus labrax fingerlings after 56 days of feeding various levels of high protein distiller's dried grains (HPDDG) with enzyme phytase.

\begin{tabular}{|c|c|c|c|c|c|}
\hline & \multicolumn{5}{|c|}{ Experimental diets } \\
\hline & Control & $\mathrm{C}^{+}$ & $\mathrm{D}_{20 \%}{ }^{+}$ & $\mathrm{D}_{30 \%}{ }^{+}$ & $\mathrm{D}_{40 \%}{ }^{+}$ \\
\hline IBW $\left(\mathrm{g} \mathrm{fish}^{-1}\right)$ & $7.55 \pm 0.05$ & $7.5 \pm 0.05$ & $7.50 \pm 0.06$ & $7.60 \pm 0.01$ & $7.60 \pm 0.03$ \\
\hline FBW $\left(\mathrm{g} \mathrm{fish}^{-1}\right)$ & $13.95 \pm 0.65^{\mathrm{d}}$ & $15.50 \pm 0.28^{\mathrm{c}}$ & $\begin{array}{c}17.60 \pm \\
0.21^{\mathrm{b}}\end{array}$ & $17.80 \pm 0.15^{b}$ & $18.92 \pm 0.21^{\mathrm{a}}$ \\
\hline BWG & $6.55 \pm 0.65^{c}$ & $7.86 \pm 0.26^{\mathrm{c}}$ & $9.80 \pm 0.15^{b}$ & $9.95 \pm 0.15^{b}$ & $10.73 \pm 0.20^{\mathrm{a}}$ \\
\hline $\operatorname{SGR}\left(\%\right.$ day $\left.^{-1}\right)$ & $1.25 \pm 0.15^{\mathrm{c}}$ & $1.25 \pm 0.11^{\mathrm{c}}$ & $1.37 \pm 0.01^{\mathrm{b}}$ & $1.45 \pm 0.02^{\mathrm{ab}}$ & $1.58 \pm 0.02^{\mathrm{a}}$ \\
\hline
\end{tabular}

Values are mean \pm SD of triplicate analyses. Means in the same row bearing different superscript differ significantly $(P \leq 0.05)$. C: control, D: HPDDG, high protein distiller's dried grains; +: phytase, IBW, initial body weight; FBW, Final body weight; BWG, body weight gain and SGR specific growth rate.

Table( 3): Nutrient utilization of European sea bass, Dicentrarchus labrax fingerlings after 56 days of feeding various levels of high protein distiller's dried grains (HPDDG) with enzyme phytase.

\begin{tabular}{lccccc}
\hline & \multicolumn{4}{c}{ Experimental diets } \\
& Control & $\mathrm{C}^{+}$ & $\mathrm{D}_{20 \%}{ }^{+}$ & $\mathrm{D}_{30 \%}{ }^{+}$ & $\mathrm{D}_{40 \%}{ }^{+}$ \\
\hline FCR & $1.70 \pm 0.07^{\mathrm{c}}$ & $1.60 \pm 0.04^{\mathrm{c}}$ & $1.40 \pm 0.05^{\mathrm{b}}$ & $1.43 \pm 0.03^{\mathrm{b}}$ & $1.20 \pm 0.03^{\mathrm{a}}$ \\
FI $\left(\mathrm{g} \mathrm{fish}{ }^{-1}\right)$ & $10.02 \pm 0.1$ & $12.13 \pm 0.49$ & $13.95 \pm 0.40$ & $13.25 \pm 0.17$ & $13.10 \pm 0.06$ \\
PER & $1.48 \pm 0.21^{\mathrm{c}}$ & $1.47 \pm 0.30^{\mathrm{c}}$ & $1.58 \pm 0.4^{\mathrm{b}}$ & $1.67 \pm 0.13^{\mathrm{b}}$ & $1.81 \pm 0.15^{\mathrm{a}}$ \\
\hline
\end{tabular}

Values are mean \pm SD of triplicate analyses. Means in the same row bearing different superscript differ significantly $(P \leq 0.05)$. C: control, D: HPDDG, high protein distiller's dried grains; + : phytase, FCR: feed conversion ratio, FI: Feed intake and PER: Protein efficiency ratio. 
Data in Table 2 shows that all fish fed HPDDG-supplemented with phytase diets resulted in higher growth than the control diet, suggesting that the using of HPDDG-supplemented with phytase enhanced the growth performance of sea bass fingerlings. The final body weight (FBW), body weight gain (BWG) and specific growth rate (SGR) of $D$. labrax increased with increasing dietary HPDDG-supplemented with phytase up to $400 \mathrm{~g} / \mathrm{kg}$. The same trend was recorded for the best FCR and PER (Table 3). For omnivorous fish species, DDGS may be used to replace fish meal and soybean meal, up to $40 \%$ of diet, without lysine supplementation (Webster et al. 1991, 1992, 1993; Lim et al. 2009) and with no negative repercussions on growth performance. Higher dietary replacement levels may be achieved with the adequate restoration of dietary essential amino acid profile, by using amino acid supplements or combination among different protein sources (Webster et al. 1991; Cheng and Hardy 2004). Webster et al. (1992) states that a combination of DDGS with soybean meal (35\% DDGS and 49\% soybean meal) can be used to totally replace in the diet, with or without lysine supplementation and methionine. In rainbow trout diets, Cheng and Hardy (2004) states that DDGS can be used at $22.5 \%$ inclusion level or at $75 \%$ with lysine and methionine supplementation. In the same species a replacement of $25 \%$ of fish meal can be achieved with a mixture of corn DDGS and corn gluten meal (Stone et al 2005). Recently, Totok et al ., (2017) reported that adding phytase enzyme supplementation of 1,000 FTU on s feed has highly significant effect to growth of Asian seabass. Wallace et al., (2016) reported thatphytase had positive potential impacts on nutrient utilization and growth responses in tilapia. FCR, AWG and SGR improved marginally with inclusions suggesting some level of enzyme counteraction on targeted ANFs ( $\mathrm{P}>0.05)$.

The addition of enzymes in diets can help to improve the utilization of dietary energy, amino acids and eliminate the effects of anti-nutritional factors (ANFs) resulting in improved performance (Gitoee $\boldsymbol{e t}$ al., 2015), due to disrupting the cell wall matrix and enhancing the contact between digestive enzyme and cell content, which resulted in improved energy and nutrient digestibility (Wu et al., 2004). Zhu et al., (2014), reported that dietary phytase supplementation significantly increased growth performance of seabass. Insignificant effects on growth performance were also reported in Japanese seabass, Lateolabrax japonicas, with the supplementation of $500 \mathrm{IU} \mathrm{kg}^{-1}$ feed phytase (Ai et al., 2007) and in 
channel catfish, Ictalurus punctatus under similar phytase treatment (Yan and Reigh 2002). However, some significantly positive effects of phytase supplementation on growth were observed in rainbow trout (Vielma et al., 2002). Therefore, phytase supplementation level is important in the effects on growth performance. The addition of exogenous enzymes to aquafeed has been reported to enhance the digestion of indigestible ingredients in some species of fish such as Altantic salmon (Carter et al. 1994), black tiger shrimp Penaeus monodon (Buchanan et al. 1997), and silver perch Bidyanus bidyanus (Stone et al. 2003).

Hematological parameters investigated are presented in Figures (1-5). Mean red blood cell counts (RBCs), mean white blood cell counts (WBCs), hematocrit (Hct), hemoglobin (Hb) (Fig. 1), total plasma protein, ,total plasma globulin (Fig. 2), Cholesterol (Fig. 3), Lysozyme (Fig. 4) and total antioxidant capacity (TAC, \%)(Fig. 5) of D. labrax fingerlings significantly $(\mathrm{P} \geq 0.05)$ increased with increasing levels HPDDG with phytase. A highly positive correlation was observed between dietary HPDDG-supplemented with phytase and WBCs $\left(\mathrm{R}^{2}=0\right.$. 976), RBCs $\left(\mathrm{R}^{2}=0.991\right)$, Hct $\left(\mathrm{R}^{2}=0.916\right), \mathrm{Hb}\left(\mathrm{R}^{2}=0.949\right)$, Cholesterol $\left(\mathrm{R}^{2}=0.962\right)$, Lysozyme $\left(\mathrm{R}^{2}=0.987\right)$ and TAC, \% $\left(\mathrm{R}^{2}=0.967\right)$.

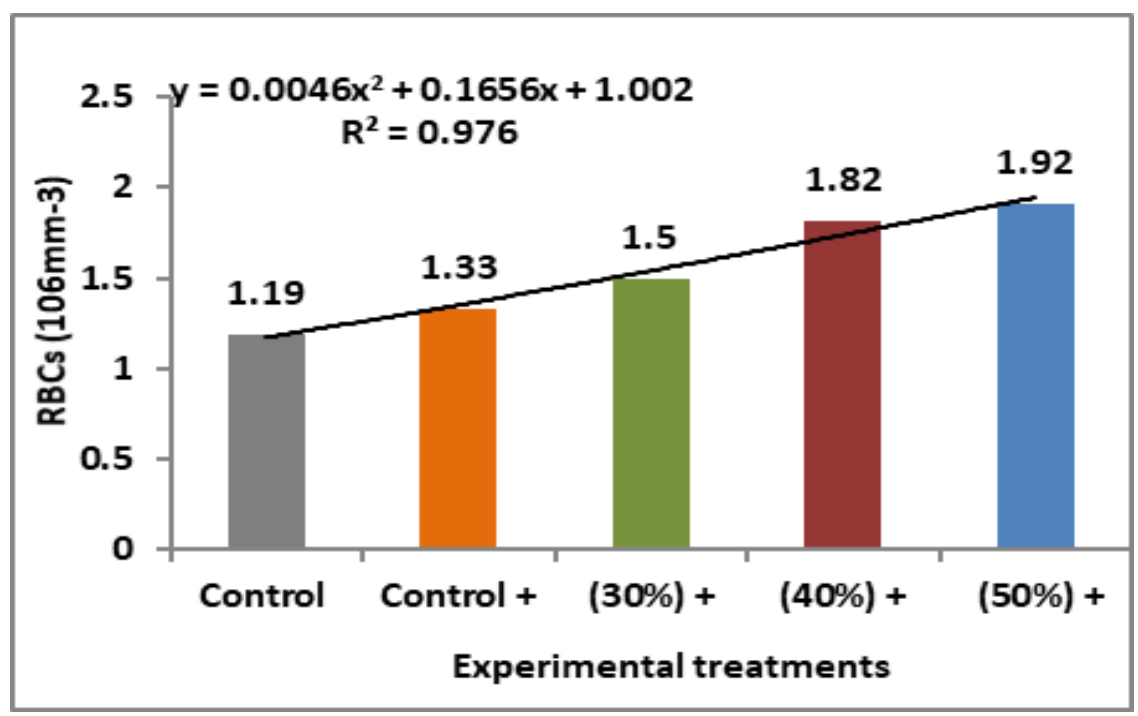



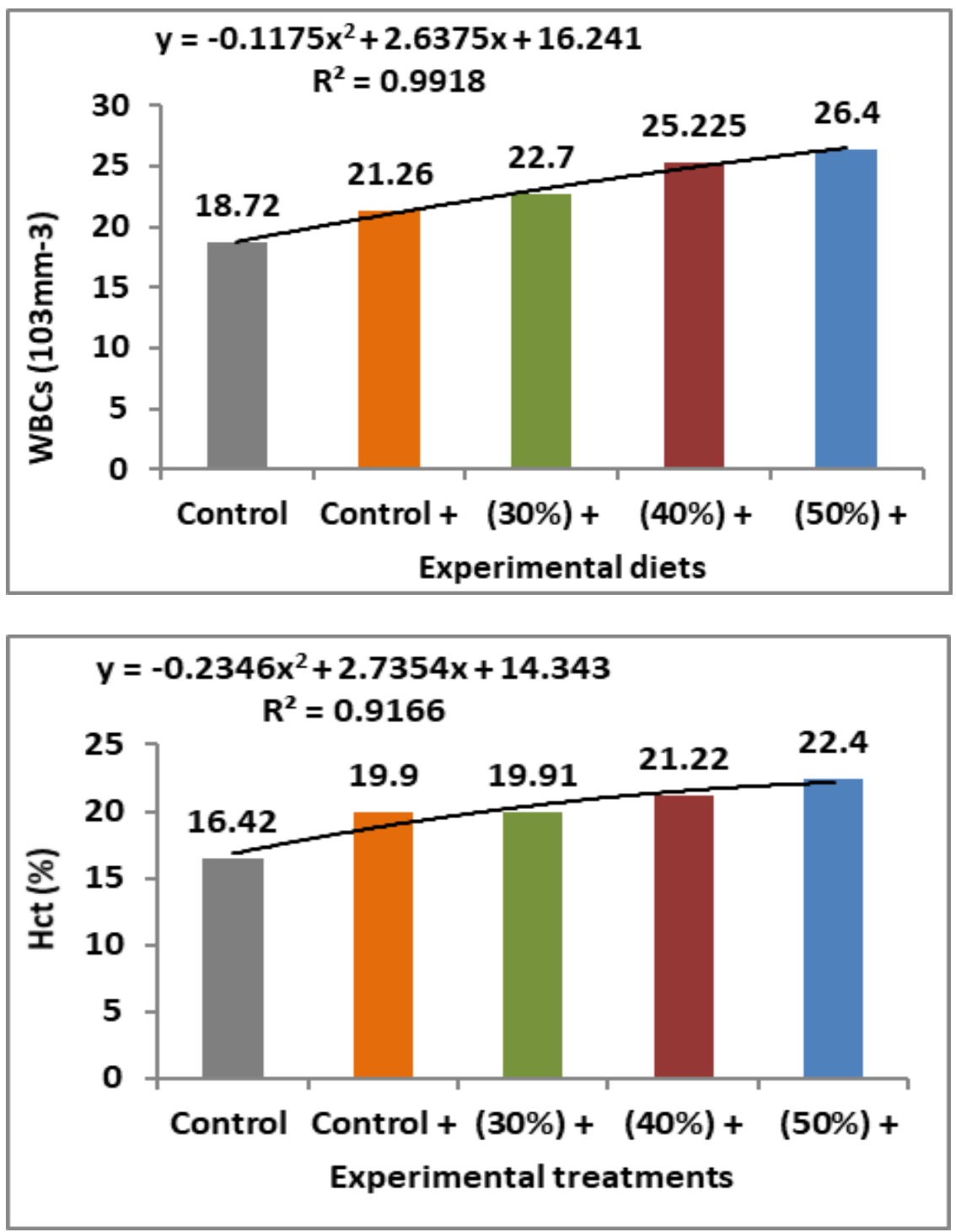


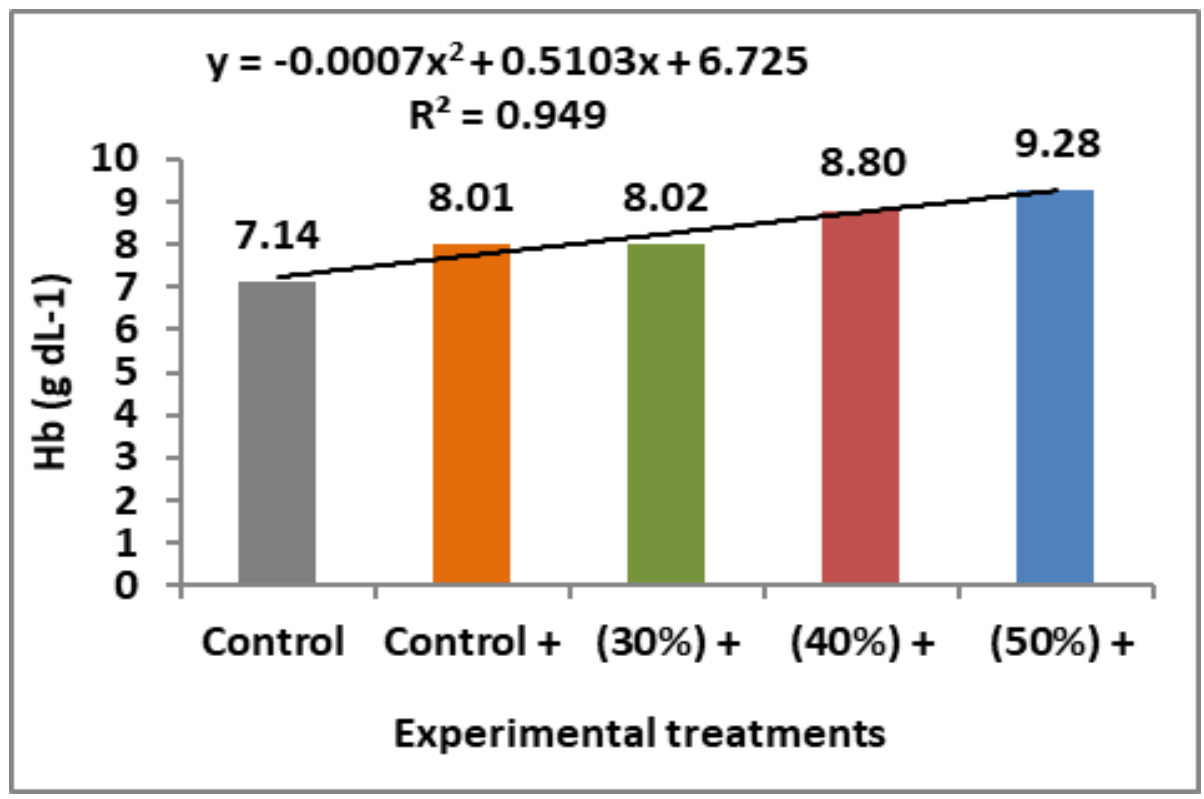

Fig. 1 Illustrated the effect of various dietary levels of high protein distiller's dried grains (HPDDG) with enzyme phytase on blood RBCs, WBCs, Hct and Hb contents of European sea bass, Dicentrarchus labrax fingerlings.

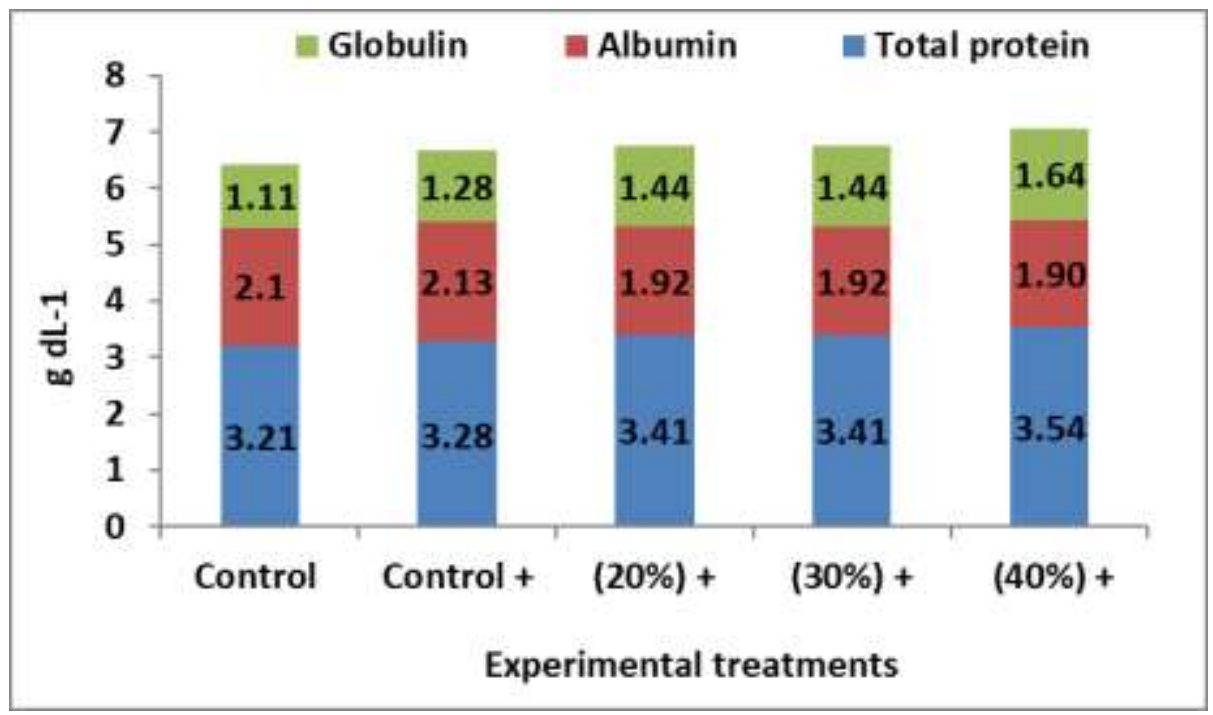

Fig. 2 Illustrated the effect of various dietary levels of high protein distiller's dried grains (HPDDG) with enzyme phytase on total serum protein, albumin and globulin of European sea bass, Dicentrarchus labrax fingerlings. 


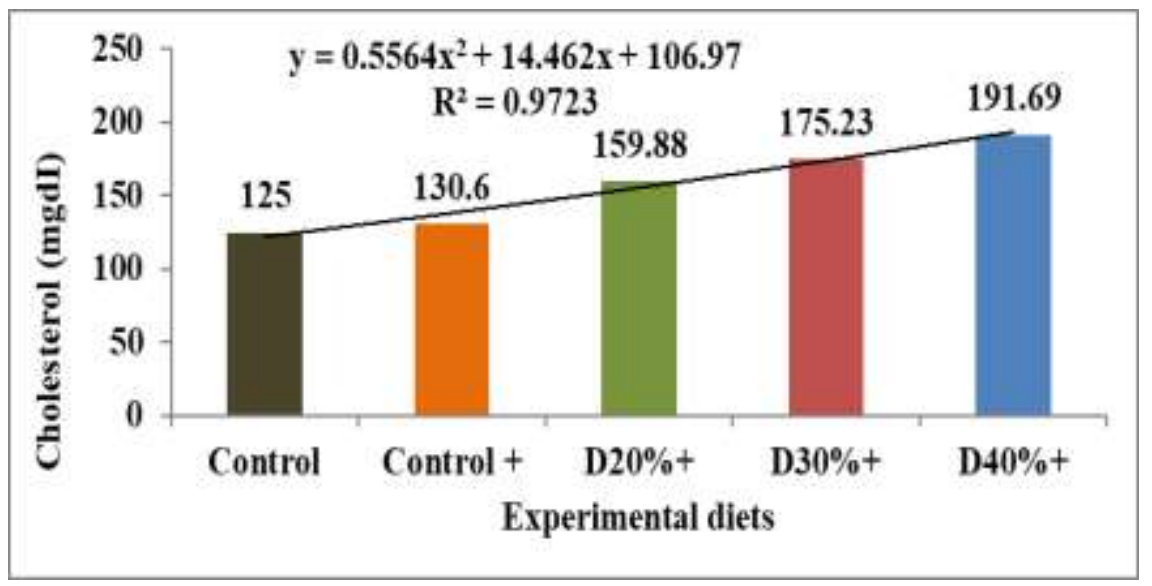

Fig. 3 Illustrated the effect of various dietary levels of high protein distiller's dried grains (HPDDG) with enzyme phytase on blood Cholesterol (mgdI) content of European sea bass, Dicentrarchus labrax fingerlings.

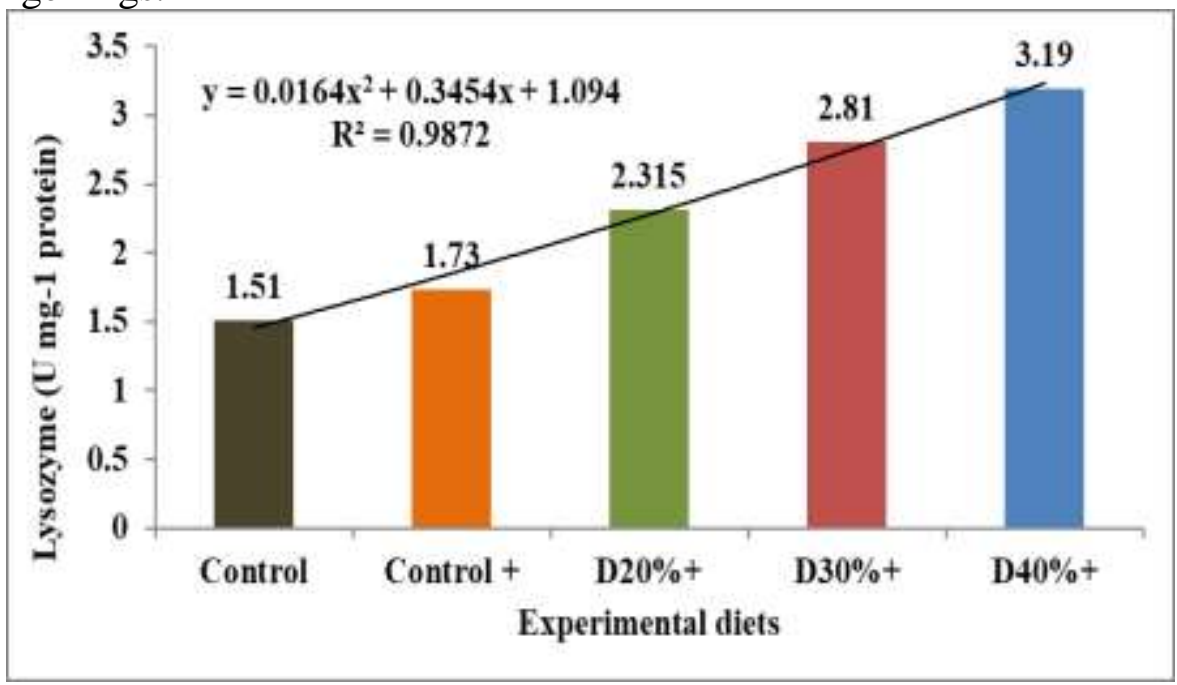

Fig. 4 Illustrated the effect of various dietary levels of high protein distiller's dried grains (HPDDG) with enzyme phytase on blood Lysozyme (U mg-1 protein) content of European sea bass, Dicentrarchus labrax fingerlings. 


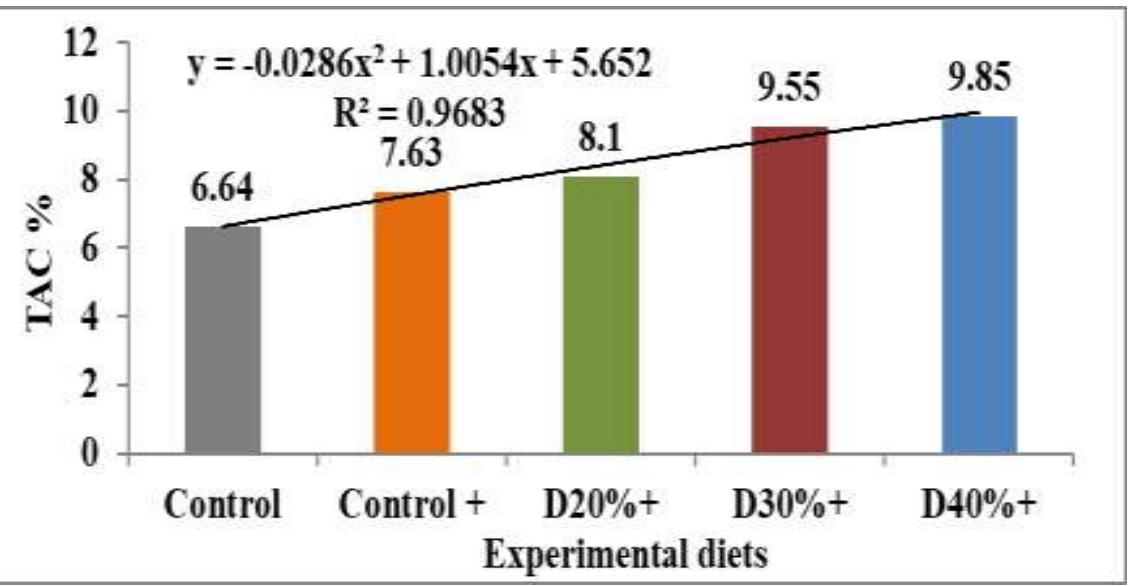

Fig. 5 Illustrated the effect of various dietary levels of high protein distiller's dried grains (HPDDG) with enzyme phytase on total antioxidant capacity (TAC\%) of European sea bass, Dicentrarchus labrax fingerlings.

Total serum protein is often used as an indicator of physiological condition in fish, as it is one of the most stable components of blood, and so an increase or decrease of total blood proteins, globulins and albumin has clinical relevance in fish. Infection may be followed by marked changes on total blood protein due to impair hepatic synthesis of blood protein, increase catabolism or losses of albumin in urine or synthesis of globulins by the immune system. High plasma albumin and/or globulin has been related to stress, inflammatory and innate immune responses or to feeding immune-stimulants. Also higher levels of plasma non-specific humoral immune parameter, such as lysozyme and complement activity, have been used as indicative of immuno-enhancing properties to certain dietary compounds (Peres $\boldsymbol{e t}$ al., 2015). The present study observed that highest hematological, biochemical and immune induces values (WBC, $\mathrm{RBC}, \mathrm{Hb}, \mathrm{Hct}$, total protein, globulin, Cholesterol, Lysozyme activity and TAC) for fish fed diets contain HPDDG compared to control. The increase in hemoglobin concentration could be attributed to the higher oxygen consumption associated with more hemoglobin saturation and dissociation rates (Yahav et al., 1998). Commercial catfish diets with high levels of phytase enzymes could significantly improve hematological parameters we observed significantly higher concentration of RBC's, WBCs, Hct\% and $\mathrm{Hb}$ concentration as a result of phytase super dose fortification to a commercial catfish ration (Peatman and Beck, 2016). However, El-Katcha et al. (2014) found that the enzyme 
supplementation had no significant effect on blood serum albumin concentrations when compared with broiler chicken group fed on the same diet without enzyme supplementation.

\section{Acknowledgements:}

The authors are grateful for all the support from the National Institute of Oceanography and Fisheries (NIOF) and Academy of Scientific Research and Technology (ASRT) for financial supported under project No. 1332 title: The national campaign to promote the fish feed industry in Egypt, especially for small and medium-producers, within the special grants program for national campaigns to promote food production in Egypt 2016-2018. The authors would like to thank the scientists at fish nutrition research laboratory teams for their kind assistance.

\section{REFERENCES}

Ai, Q.; Mai, K.;Zhang, W.;Xu, W.; Tan, B.;Zhang, C. and Li, H. (2007).Effects of exogenous enzymes (phytase, non-starch polysaccharide enzyme) in diets on growth, feed utilization, nitrogen and phosphorus excretion of Japanese seabass, Lateolabraxjaponicus. Comp. Biochem. Physiol. A 147, 502-508.

Ambasankar, K.; Ahmad Ali, S. and Syamadayal, J. (2009). Nutritional Requirements of AsianSeabass, Latescalcarifer. In: Coursemanual: National Training on CageCulture (Ed. Imelda Joseph et al.),Central Marine Fisheries ResearchInstitute. December 14-23, 2009. Cochin.pp. 60-65.

Bae, K.M.; Kang-Woong Kim, K. W. and Lee, S. M. (2015). Evaluation of rice distillers dried grain as a partial replacement for fish meal in the practical diet of the juvenile olive flounder Paralichthysolivaceus. Fish AquatSci 18, 151-158.

Bonaldo, A.; Di Marco, P.; Petochi, T.; Marino, G.;Parma, L.;Fontanillas, R.; Koppe, W.; Mongile, F.; Finoia, M.G and Gatta, P.P. (2015). Feeding turbot juveniles Psetta maxima L. with increasing dietary plant protein levels affects growth performance and fish welfare. Aquac.Nutr.21,401-413.

Brett, J.R. (1973). Energy expenditure of Sockeye salmon, Oncorhynchusnerka, during sustained performance. Journal of Fish Research Board of Canada 30 (12/1): 1799 - 1809. 
Buchanan, J.; Sarac, H. Z. ; Poppi, D. and R. T. Cowan .(1997). Effects of enzyme addition to canola meal in prawn diets. Aquaculture,151, 29-35.

Carter ,C.G.; Houlihan ,D.F.; Buchanan B. and McCarthy I.A. (1994). Growth and feed utilization eficiencies of seawater Atlantic salmon Salmosalar L. fed a diet containing supplementary enzymes. Aquaculture and Fisheries Management25, 37-46.

Castell.J.D. and Tiewes.K. (1980).Report of the EIFAC.IUNS and ICES working group on the standardization of methodology in fish research. Hamburg. FRG.21-23March 1979.IFAC tech.pap. (3)24.

Castillo, S. and Gatlin, D.M.( 2015). Dietary supplementation of exogenous carbohydrase enzymes in fish nutrition: a review. Aquaculture 435, 286-292

Cheng, Z.J. and Hardy, R.W. (2004). Nutritional value of diets containing distillers dried grains with solubles for rainbow trout, Oncorhynchus mykiss. J. Appl. Aquac., 15, 101-113.

Cho C.Y. (1990). Fish nutrition, feeds and feeding: with special emphasis on salmonid aquaculture. Food Reviews International 6, 333-357.

Dalsgaard, J.; Bach Knudsen, K.E.; Verlhac, V.; Ekmann, K.S. and Pedersen, P.B.(2014). Supplementing enzymes to extruded, soybeanbased diet improves breakdown of non-starch polysaccharides in rainbow trout (Oncorhynchusmykiss). Aquacult.Nutr.Doi: 10.1111/anu.12258.

Dalsgaard, J.;Verlhac, V.;Hjermitslev, N.H.; Ekmann, K.S.;Fischer, M.;Klausen, M. and Pedersen, P.B.(2012). Effects of exogenous enzymes on apparent nutrient digestibility in rainbow trout (Oncorhynchusmykiss) fed diets with high inclusion of plant-based protein. Anim. Feed Sci. Technol. 171, 181-191.

Danwitz, A.; von, C.G.J.;van Bussel.; S.F. Klatt,C. and Schulz. (2016). Dietary phytasesupplementation in rapeseed proteinbased diets influences growthperformance, digestibility and nutrientutilisation in turbot (Psetta maxima L.).Aquaculture 450: 405-411.

Dersjant-Li, Y.A.; Awaiti, A.; Schulze, H. and Partridge, G. (2015).Phytase in non-ruminant animal nutrition: a critical review on phytase activities in the gastrointestinal tract and influencing factors. Journal of the Science of Food and Agriculture 10.1002:878. 
Doumas, B.T.; Bayse, D.; Carter, R.J.; Peters , T. and Schaffer, R. (1981). A candidate reference method for determination of total protein in serum: I Development and validation. Clin. Chem., 27, 1642-1650.

Drabkin, D. (1945).Spectrophotometric methods XIV. The crystographic and optical properties of the haemoglobin of man in comparison with those of other species. J.Biol.Chem.164, 703 - 723.

Duncan, D. B. (1955). Multiple range and multiple F test. Biometric, $11: 1-42$

El-Katcha, M. I.; Soltan , M. A.; El-Kaney ,H. F. and El-Sayed ,R. (2014). Growth performance, blood parameters, immune response and carcass traits of broiler chicks fed on graded levels of wheat instead of corn without or with enzyme supplementation. Alexandria Journal of Veterinary Sciences, 40:95-111.

Ellis, A. E. (1990): Lysozyme Assays. In: Techniques in Fish Immunology, Stolen, J. S., T. C. Fletcher, D. P. Anderson and W. B. van Muiswinkel (Eds.). Vol. 1, SOS Publications, New Jersey, USA, pp. 101-103.

FAO.(2018).The State of World Fisheries and Aquaculture 2018.Contributing to food security and nutrition for all.

Farhangi, M. and Carter, C.G. (2007). Effect of enzyme supplementation to dehulledlupin-based diets on growth, feed efficiency, nutrient digestibility and carcass composition of rainbow trout, Oncorhynchusmykiss (Walbaum). Aquacult. Res. 38, 1274-1282.

Forster, I.; Higgs ,D. A.; Dosanjh ,B. S.; Rowshandeli, M. and Parr ,J. (1999). Potential for dietary phytase to improve the nutritive value of canola protein concentrate and decrease phosphorus output in rainbow trout (Oncorhynchusmykiss) held in $11{ }^{\circ} \mathrm{C}$ fresh water. Aquaculture, 179, 109-125.

Galaktionova,L.P.; Molchanov,A.V.; El'chaninova, S.A. and Varshavskii, B.I.(1998). Lipid peroxidation in patients with gastric and duodenal peptic ulcers - Klin. Lab. Diagn. 6,10-14.

Gitoee, A.; Janmohammadi, H.;Taghizadeg, A. and Rafat, S.A. (2015). "Effects of multi-enzyme on performance and carcass characteristics of broiler chickens fed corn-soybean meal basal diets with different metabolizable energy levels".Journal of Applied Animal Research, 2015 Vol. 43, No. 3, 295-302. 
Kim, D.H. and Austin, B. (2006).Innate immune responses in rainbow trout (Oncorhynchusmykiss, Walbaum) induced by probiotics. Fish\& Shell fish immunology, 21: 513-524.

Leng, X.J.; Liu, D.Y.; Li, X.Q. and Lu, Y.H.(2008). Effects of adding protease $\mathrm{AG}$ on growth and digestive protease activities of common carp (Cyprinuscarpio) fingerling. Chin. J. Anim. Nutr. 20, 268-274.

Li, M.H.; Oberle, D.F. and Lucas, P.M.(2011a). Evaluation of corn distillers dried grains with solubles and brewers yeast in diets for channel catfish Ictaluruspunctatus (Rafinesque). Aquac. Res. 42, 1-7.

Li, X.Q.; Chai, X.Q.; Liu, D.Y.; Chowdhury, M.A.K. and Leng, X.J.( 2015). Effects of temperature and feed processing on protease activity and dietary protease on growths of white shrimp, Litopenaeusvannamei, and tilapia, Oreochromisniloticus $\times \mathrm{O}$. aureus. Aquacult.Nutr.Doi: 10.111/anu.12330.

Lim, C., Yildirim-Aksoy, M. and Klesius ,P. H. (2009). Growth response and resistance to Edwardsiella ictaluri of channel catfish, Ictalurus punctatus, fed diets containing distiller's dried grains with soluble. Journal of the World Aquaculture Society, 40:182-193.

Lin, S.; Mai, K. and Tan, B.(2007). Effects of exogenous enzyme supplementation in diets on growth and feed utilization in tilapia, Oreochromisniloticus $\times$ O. aureus.Aquacult. Res. 38, Liu, L.; Su, J.; Zhang, T.; Liang, X.F. and Luo, Y. (2013). Apparent digestibility of nutrients in grass carp (Ctenopharyngodonidellus) diet supplemented with graded levels of neutral phytase using pretreatment and spraying methods. Aquacult.Nutr., 19, 91-99.

Liu, K. S. (2011). Chemical composition of distillers grains, a review. J. Agric. Food Chem. 59, 1508-1526.

Liu, L., Su, J., Zhang, T., Liang, X.F. \&Luo, Y. (2013). Apparent digestibility of nutrients in grass carp (Ctenopharyngodonidellus) diet supplemented with graded levels of neutral phytase using pretreatment and spraying methods. Aquacult.Nutr., 19: 91-99.

Magalhães, R.; Lopes, T.; Martins, N.; Díaz-Rosales, P.; Couto, A.; Pousão-Ferreira, P.;Oliva-Teles, A. and Peres, H.(2016). Carbohydrases supplementation increased nutrient utilization in white seabream (Diplodussargus) juveniles fed high soybean meal diets. Aquaculture 463, 43-50. 
Mathlouthi, N.; Lallès, J.P.; Lepercq, P.; Juste, C. and Larbier, M. (2002). Xylanase and beta-glucanasesupplementation improve conjugated bile acid fraction in intestinal contents and increase villus size ofsmall intestine wall in broiler chickens fed a rye-based diet. J. Anim. Sci, 80:2773-2779.

Matos, E.; Dias, J.; Dinis, M.T . and Silva, T.S. (2016). Sustainability vs. Quality in gilthead seabream (Sparusaurata L.) farming: are trade-offs inevitable? Reviews in Aquaculture.

NASS. (2016). Catfish Production. Agricultural Statistics Board, United States Department of Agriculture. Available at: http://usda.mannlib.cornell.edu/usda/nass/CatfProd.

Nie, G.; Hua, X.; Wang, J.; Ming, H.; Song, D. and Zhou, H. (2009) .The influences of xylanase added in wheat basal diet on intestinal microflora of Oreochromisniloticus. J. Fish. China, 33, 805-812.

Overland, M.; Krogdahl, A.; Shurson, G.; Skrede, A. and Denstadli, V. (2013). Evaluation of distiller's dried grains with solubles (DDGS) and high protein distiller's dried grains (HPDDG) in diets for rainbow trout (Oncorhynchusmykiss). Aquaculture 416, 201-208.

Peatman, E. and Beck, B.H. (2016). From floor sweepings to fish flesh phytasesuperdosing in the US catfish industry. Phytate destruction consequences for precision animal nutrition. pp. 237-250.

Peres, H.; Costas, B.; Perez-Jimenez, A.;Guerreiro, I. and Oliva-Teles, A.(2015). Reference values for selected hematological and serum biochemical parameters of Senegalese sole (SoleasenegalensisKaup, 1858) juveniles under intensive aquaculture conditions. J. Appl. Ichthyol. 31 , 65-71. http://onlinelibrary.wiley.com/doi/10.1111/jai.12641/abstract

Prieto, P.; Pineda, M. and Aguilar, M. (1999). Spectrophotometric quantitation of antioxidant capacity through the formation of a phosphomolybdenum complex: Specific application to the determination of vitamin E. Anal Biochem. 269, 337-41.

Rahman, M.M.; Choi, J. and Lee, S. M. (2015). Use of distillers dried grain as a cost effective ingredient in the diet of juvenile olive flounder (Paralichthysolivaceus). Isr. J. Aquacult. Bamidgeh 67, 9.

Reinhold, R.R. (1953). Determination of serum albumin. Clin. Chem., 21: $1370-1372$. 
Rosentrater, K. A. and K. Muthukumarappan . (2006). Corn ethanol coproducts: generation, properties, and future prospects. International Sugar Journal.108,648-657.

SAS.(2004). Statistical Analysis System User's Guide (version 9). SAS Institute, Inc., Cary, North Carolina, USA.

Selle, P.H. and Ravindran, V. (2007).Microbial phytase in poultry nutrition.Animal Feed Science and Technology. 135.1-2:1-41.

Soltan, M.A. (2009). Effect of dietary fish meal replacement by poultry by-product meal with different grain source and enzyme supplementation on performance, feces recovery, body composition and nutrient balance of Nile tilapia. Pakistan J.Nutr., 8, 395-407.

Stone, D.A.J.; Allan ,G. L.and Anderson ,A. J. (2005). Carbohydrate utilization by juvenile silver perch,Bidyanusbidyanus(Mitchell) IV. Can dietary enzymes increase digestible energy from wheatstarch, wheat and dehulledlupin?Aquac. Res., 34,135-147.

Stoskopf, M. K. (1993). Fish Medicine W.B. Saunders Comp. Philadelphia.

Tidwell, J. H.; Coyle, S. D.; Bright1, L. A . and Pires, L .(2017) .Effects of Varying Levels of High-Protein Distiller's Grains on Growth Performance of Channel Catfish, Ictaluruspunctatus, and PostExtrusion Feed Pellet Characteristics. JOURNAL OF THE WORLD AQUACULTURE SOCIETY.48, 426-434.

Totok Yudhiyanto.; Suminto. and Diana Rachmawati.(2017). The Effect of Dietary Soybean Meal with Phytase Supplementation on Digestibility and Growthof Asian SeabassLatescalcarifer. OmniAkuatika, 13 (2): 144 - 154, 2017.

Vielma, J.; Ruohonen, K. and Peisker, M. (2002).Dephytinization of two soy proteins increases phosphorus and protein utilization by rainbow trout, Oncorhynchusmykiss. Aquaculture 204, 145-156.

Wallace ,J. L.; Murray, F. J. and Little ,D. C.(2016). Effects of bxylanase and 6-phytase on digestibility, trace mineral utilisation and growth in juvenile red tilapia, Oreochromisniloticus (Linnaeus, 1758) $\mathrm{x}$ O. mossambicus (Peters, 1852), fed declining fishmeal diets. J. Appl. Ichthyol. 32 (2016), 471- 
Webster, C.D.; Tidwell, J.H. and Yancey, D.H. (1991). Evaluation of distillers grains with solubles as a protein source in diets for channel catfish. Aquaculture, 96: 179-190.

Webster, C.D.; Tidwell, J.H. and Goodgame, L.S. (1993). Growth, body composition, and organoleptic evaluation of channel catfish fed diets containing different percentages of distillers grains with solubles. Prog. Fish Cult, 55: 95-100.

Webster, C.D.; Tidwell, J.H.; Goodgame, L.S.; Yancey, D.H. and Mackey, L. (1992). Use of soybeanmeal and distillers grains with solubles as partial or total replacement of fish meal indiets for channel catfish, Ictalurus punctatus. Aquaculture ,106: 301-309.

Welker, T.L.; Lim, C.; Barrows, F.T. and Liu, K. (2014b). Use of distiller's dried grains with solubles (DDGS) in rainbow trout feeds. Anim. Feed Sci. Technol. 195, 47-57.

Welker, T.L.; Lim, C.; Klesius, P. and Liu, K. (2014a). Evaluation of distiller's dried grains with solubles from different grain sources as dietary protein for hybrid tilapia, (Oreochromis niloticus $\times$ Oreochromis aureus). J. World Aquac. 45, 625-637.

Wu, Y.B.; Ravindran, V.;Thomas, D.G.; Birtles, M.J. and Hendriks, W.H. (2004). Influence of phytase and xylanase, individually or in combination, on performance, apparent metabolisable energy, digestive tract measurements and gut morphology in broilers fed wheat-based diets containing adequate level of phosphorus. British Poultry Science45:76- 84.

Yahav, S.; Lugar ,D.; Cahaner ,A.; Dotan ,M.; Ruzan M. and Hurwitz, S. (1998). Thermoregulation in naked neck chickens subjected to different ambient temperatures. British Poultry Science. (39): 133138.

Yan, W. and Reigh, R. C. (2002). Effects of fungal phytaseonutilization of dietary protein and minerals, anddephosphorylation of phytic acid in the alimentarytract of channel catfish Ictaluruspunctatus fed anallplant protein diet. Journal of the World AquacultureSociety ,33: 1022.

Yoo, G. Y.; Wang, X. J.; Choi, S. M. and Han, K. M. (2005). Dietary microbial phytase increased the phosphorus digestibility in juvenile Korean rockfish Sebastesschlegeli fed diets containing soybean meal. Aquaculture, 243: 315-322. 
Yousefi, M.; Abtahi, B.; Kenari, A . (2011). Hematological, serum biochemical parameters, and physiological responses to acute stress of Beluga sturgeon (Husohuso, Linnaeus 1785) juveniles fed dietary nucleotide. Comparative Clinical Pathology, 1-6.doi: 10.1007/s00580011-1225-4.

Zhu, Y.; Qiu, X.; Ding, Q.; Duan, M.;Wang, C.(2014). Combined effects of dietary phytase and organic acid on growth and phosphorus utilization of juvenile yellow catfish Pelteobagrusfulvidraco. Aquaculture 430, 1-8. 


\section{إستخدام نواتج تقطير الحبوب العالية البرويتن مع انزيم القيتاز فى النظام

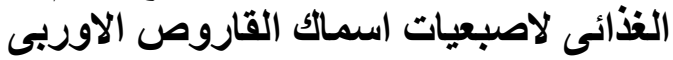

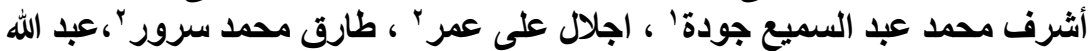

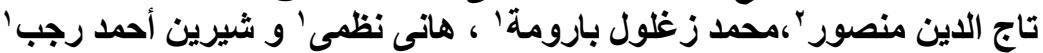

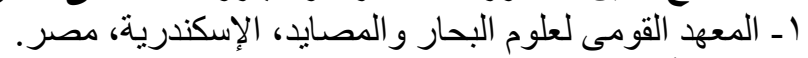

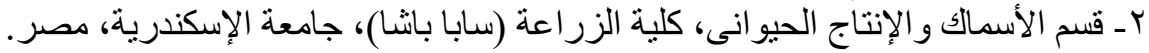

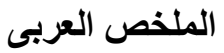

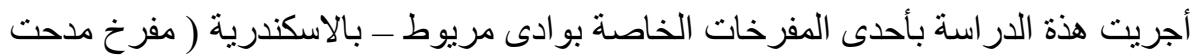

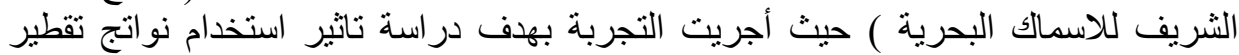

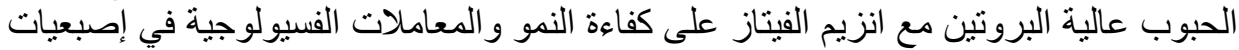
أسمالك القاروص البحر البرونين الأوروبي. النزيم الفيت

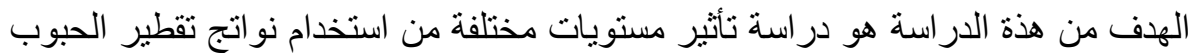

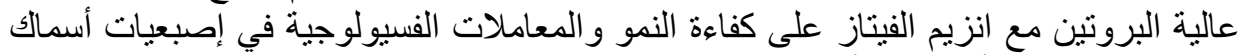

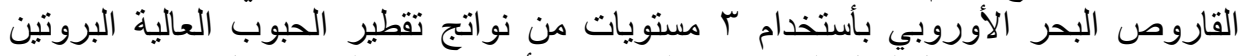

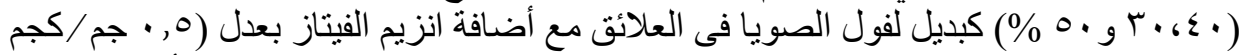

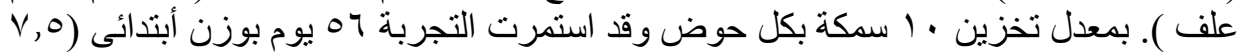

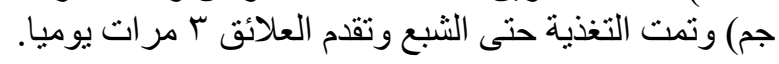

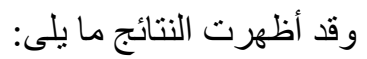

تحسن النمو مع زيادة مستويات نواتج تقطير عالية البروتين مع انزيم الفيتاز فى العليقة

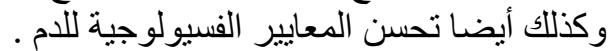

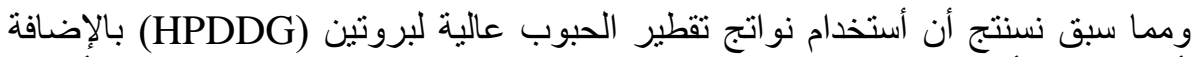

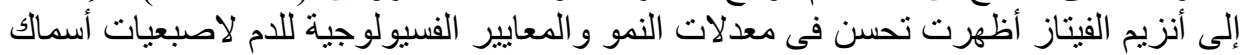

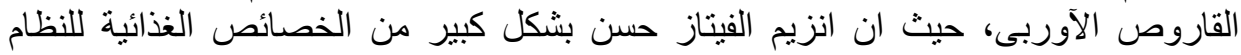

